\title{
Evaluation of Sugarcane Genotypes Under Irrigation Based on Genetic Variations and Heritability for Agronomic Traits at Early Selection Stage in Ferké, Ivory Coast
}

\author{
Crépin Bi Péné ${ }^{1}$, Yavo Mickle Béhou ${ }^{2}$ \\ ${ }^{1}$ Research and Development Department, Ferké 1\&2 Sugar Estates, SUCAF-CI/SOMDIAA Company, Abidjan, Ivory Coast \\ ${ }^{2}$ Department of Agronomy, Agricultural Engineering and Forestry, Doctoral College, Polytechnic Institute Houphouet-Boigny, \\ Yamoussoukro, Ivory Coast
}

\section{Email address:}

bpene@sucafci.somdiaa.com (C. Bi Péné)

\section{To cite this article:}

Crépin Bi Péné, Yavo Mickle Béhou. Evaluation of Sugarcane Genotypes Under Irrigation Based on Genetic Variations and Heritability for Agronomic Traits at Early Selection Stage in Ferké, Ivory Coast. American Journal of Bioscience and Bioengineering.

Vol. 7, No. 6, 2019, pp. 82-92. doi: 10.11648/j.bio.20190706.12

Received: August 6, 2019; Accepted: October 30, 2019; Published: December 25, 2019

\begin{abstract}
The objective of the study was to determine the best performing sugarcane genotypes tested at early selection stage under sprinkler irrigation, in comparison with a check variety (R579). The experiment was designed following a randomized complete block ( $\mathrm{RCB}$ ) with 21 cane genotypes in three replications. Each plot consisted of five dual rows of ten meters with 0.5 and $1.90 \mathrm{~m}$ of inter-row spacing, i.e. $95 \mathrm{~m}^{2}$ per plot and about $6,000 \mathrm{~m}^{2}$ for the whole experiment. It was carried out on a commercial sugarcane plantation of Ferké 2 located in the northern part of the country, over two seasons (plant cane and first ratoon) as an early-season crop from, November 18, 2016 to November 15, 2018. Over each micro-plot, data based on different agro-morphological traits were collected at harvest from three central dual rows. The study showed that most relevant traits in genotype clustering were related to juice quality (recoverable sucrose, sucrose content, purity), yields and yield components (millable stalk number/ha, stalk height, stalk diameter, internode number). Based on sugar yields, four genotypes equivalent to the check (R579), namely KQ228, R97-6177, R99-4064 and KQ236, were found promising for the next advanced selection stage with, respectively, 19.2, 17.7, 17.3 and $16.9 \mathrm{t}$ sugar/ha. Their cane yield performances ranged from 147.7 to 170.8 t/ha compared to 170.7 for the check and belong to 3 clusters genotypes over the eight determined. Not only sugar yield, but also flowering rate, stem borer infestation rate and number of tillers per hectare were found as the most relevant agro-morphological traits in the genetic variation of sugarcane genotypes tested.
\end{abstract}

Keywords: Phenotypic Correlation, Genotypic Correlation, Coefficient of Variation, Genetic Advance, Yield Trait, Juice Quality

\section{Introduction}

Due to its very high biomass production, well-established farming, harvesting and processing technologies, sugarcane is a leading candidate for bioenergy production and a feedstock for bio-refineries. However, productivity improvements in sugarcane have been negligible in the past three decades, and production statistics are reflecting decreased yields globally [1]. In all cases, increased sugarcane production is linked to expansion of land surface rather than increase in yield [2].

Commercial sugarcane varieties under cultivation are complex polyploid which heterozygous nature has resulted in generations of higher genetic variability. Information about the nature and magnitude of variability present in the genetic material is of prime importance for breeders to conduct effective selection programs. Genotypic and phenotypic coefficients of variation together with heritability and genetic advance are key elements to improve any trait of sugarcane, as this would assist in knowing whether or not specific objectives targeted could be achieved from a given crop material [3-4].

In Ivory Coast and many tropical countries, sugarcane used to be the major source of sugar production. In the past 
time, this crop was cultivated traditionally in the country mainly for chewing purpose by small holder farmers. Commercial sugarcane production in Ivory Coast started in 1974 at Ferké 1 plantations on about 5,500 ha. Nowadays, sugarcane is grown on around 30,000 ha and the four sugar mills located in three different regions of the country produce about 200,000 t sugar per annum [5]. This production does not meet the domestic consumption which is estimated to about 240,000 t. Therefore, the deficit is being offset by imported sugar. To alleviate the gap between supply and demand of sugar, besides expanding the existing sugarcane mill plantations, a productivity improvement and capacity building project has been implemented in the country since 2009 with the assistance of the European Union (EU) [6].

In sugarcane, cane and sugar yields are considered as complex characters which phenotypic and genotypic interrelationship with their component traits would be of importance to breeders. Understanding associations between traits is of great importance in breeding and selection studies, especially for low heritability or hardly measuring traits [79]. Genetic relationships between important attributes in studying sugarcane populations through breeding and direct selection is crucial, primarily to understand how changes made by selecting on character may cause changes in others [10-11]. This knowledge can be used when determining effective selection strategies for particular traits in a sugarcane breeding program [12]. Likewise, number of millable stalk, stalk height and stalk diameter were reported to be positively associated with cane yield [13-14]. Similarly, phenotypic associations between yield and its components in sugarcane showed that selecting for stalk number, diameter and length should be emphasized in sugarcane variety development programs where high cane yields were the primary goal [15].

The objective of study was to determine the best performing sugarcane genotypes under irrigation at early selection stage for different agro-morphological traits based on their genetic variations and heritability.

\section{Material and Methods}

\subsection{Site Characteristics}

The study was carried out on Ferké 2 sugarcane field N1005 , sprinkler irrigated with center pivot, in northern Ivory Coast $\left(9^{\circ} 20^{\prime}-9^{\circ} 60^{\prime} \mathrm{N}, 5^{\circ} 22^{\prime}-5^{\circ} 40^{\prime} \mathrm{O}, 325 \mathrm{~m}\right.$ a. s. 1.). The prevailing climate is tropical dry with two seasons: one, starting from November to April, is dry and the other, from May to October, is wet. The dry season is marked by the northern trade wind which blows over mid-November to late January. The rainfall pattern is unimodal and centered on August and September which total amount of rainfall reaches almost half of the average annual rainfall $(1200 \mathrm{~mm})$ with an average daily temperature of $27^{\circ} \mathrm{C}$. Average maximum and minimum daily air temperatures are 32.5 and $21^{\circ} \mathrm{C}$, respectively. To meet sugarcane crop water requirements, the total amount of irrigation water required reaches 700 mm/year [16-17]. Both Ferké sugar mill plantations cover around 15500 ha with 10000 ha under irrigation and 3500 ha of rainfed village plantations, lie mainly on shallow or moderately deep soils built up on granites. Main soil units encountered are ferralsols and temporally waterlogged soils in valley bottoms of Bandama and Lokpoho river basins with a sandy-clay texture.

\subsection{Cane Genotypes Used}

All 21 cane genotypes tested were commercial varieties of four different origins (Australia, Sudan, Reunion and Mauritius). They were provided by the Montpellier sugarcane quarantine of CIRAD (International Centre for Agricultural Research and Development) in France. The heterozygous and polyploidy nature of sugarcane has resulted in generations of greater genetic variability. Knowledge on the nature and the magnitude of variability present in the genetic material is therefore of prime importance for breeders to conduct an effective selection program. Coefficients of variation along with heritability as well as genetic advance are very essential to improve any trait of sugarcane because this would help in knowing whether or not the desired objective can be achieved from the material to be investigated [18].

\subsection{Experimental Design}

The experiment was carried out over two consecutive years, as early-season trial in plant and first ratoon crops, from November 18, 2016 to November 15, 2018 following a randomized complete block design (RCBD) with 21 different genotypes, including the check (R579), in 3 replicates. A plot comprised 5 dual rows of $5 \mathrm{~m}$ long with narrow and wide spacings of $0.50 \mathrm{~m}$ and $1.90 \mathrm{~m}$. Field managements in terms of sprinkler irrigation, fertilizer and herbicide applications were done according to usual practices in commercial plantations. NKP fertilizer (16-8.5-23) was applied mechanically at the routine rates of $700 \mathrm{~kg} / \mathrm{ha}$ in plant cane and $720 \mathrm{~kg} / \mathrm{ha}$ in first ratoon. Pre-emergence chemical weeding based on pendimethalin combined with clorimuronethyl (3.5 1/ha) was achieved mechanically two day after planting.

\subsection{Agronomic Traits Investigated}

Data were collected at harvest from three central dual rows for millable stalk number/ha, cane yield, agro-morphological traits (stalk weight, stalk diameter, stalk height, number of internodes, flowering rate), juice quality traits (sucrose, purity, and recoverable sucrose), fiber content, and damaged internodes by stem borer Eldana saccharina W. (Lepidoptera: Pyralidae).

At harvest, burned cane fresh production of the three dual rows of each plot was weighed separately to determine crop yield. Moreover, 50 millable stalks were randomly chosen within every plot and split longitudinally with a machete in order to determine the percentage of bored or attacked internode and cane $(\% \mathrm{BIN}, \% \mathrm{BC})$ by stem borer.

Thirty millable cane stalks were sampled per plot for 
sucrose analyses in the laboratory. Prior to sample crushing operations in the laboratory for sucrose analyses, every stalk was cut into 3 pieces of almost equal length while separating them in basal, median and top parts. This allowed to randomly reconstitute 3 batches of 10 stalks for a better homogenization of the initial field sample by permutation of the pieces so that each reconstituted stalk was composed of parts coming from 3 different cane stalks. Eventually, only one batch of 10 reconstituted stalks over 30 (1/3 of initial sample) were crushed for a series of sucrose analyses to determine the sucrose content $(\mathrm{Pol} \% \mathrm{C})$, fiber content (Fiber \%C), juice purity (Purity \%C) and recoverable sucrose $(\mathrm{SE} \% \mathrm{C})$. Equipment used comprised a Jefco cutter grinder, a hydraulic press (Pinette Emideceau), a digital refractometer BS-RFM742 and a digital polari-meter SH-M100. Methods used in the determination of required technological parameters were reported by Hoarau [19]. The recoverable sucrose was calculated as follows $[6,20]$ :

$\mathrm{SE} \% \mathrm{C}=\left[(0.84 \times \mathrm{Pol} \% \mathrm{C})\left(\begin{array}{lll}1.6 & -60 / \text { Purity }) & -\end{array}(0.05 \times\right.\right.$ Fib \%C)] with:

Purity $\% \mathrm{C}=($ Pol juice/Brix $) \times 100$ and Pol juice $=$ Pol factor $\times$ Pol read.

\section{Pol $\% \mathrm{C}=$ Factor $\mathrm{n} \times$ Pol juice}

Factor pol depending on brix value (amount of soluble dry matter in juice measured with a refractometer) is provided by Schmidt table relative to a polarimeter for $26 \mathrm{~g}$ of glucose. The fiber content and factor $\mathrm{n}$ were provided by a table depending on the weight of fiber cake obtained after pressing $500 \mathrm{~g}$ of cane pulp resulting from the crushing operation of every sample of cane stalks.

\subsection{Phenotypic and Genotypic Coefficients of Variation, Heritability and Genetic Advance}

The phenotypic and genotypic variances for each trait were estimated from the RCBD analysis of variance (Table 1). The expected mean squares under the assumption of random effect model were determined from linear combinations as follows (Burton and Davane [21], cited by Shitahum et al [22]:

$$
\begin{gathered}
\text { Genotypic variance }\left(\sigma_{\mathrm{g}}^{2}\right)=\left(\mathrm{MS}_{\mathrm{g}}-\mathrm{MS}_{\mathrm{e}}\right) / \mathrm{r} \\
\text { Environmental variance }\left(\sigma_{\mathrm{e}}^{2}\right)=\mathrm{MS}_{\mathrm{e}} \\
\text { Phenotypic variance }\left(\sigma_{\mathrm{p}}^{2}\right)=\sigma_{\mathrm{g}}^{2}+\sigma_{\mathrm{e}}^{2}
\end{gathered}
$$

Where MSg and MSe are mean sum of squares for genotypes and error in the analysis of variance, respectively, and $r$ the number of replicates.

Genotypic and phenotypic coefficients of variation (GCV, PCV) were computed as follows [23]:

$$
\begin{aligned}
& \mathrm{GCV}=\sigma_{\mathrm{g}} \times 100 / \text { grand mean } \\
& \mathrm{PCV}=\sigma_{\mathrm{p}} \times 100 / \text { grand mean }
\end{aligned}
$$

Broad sense heritability $h^{2}=100 \times \sigma_{\mathrm{g}}^{2} / \sigma_{\mathrm{p}}^{2}$.
Genetic advance (GA) and genetic advance as percent mean (GAM): $\mathrm{GA}=\mathrm{k} \times \mathrm{h}^{2} \times \sigma_{\mathrm{p}}$ and $\mathrm{GAM}=100 \times \mathrm{GA} / \mathrm{X}$.

With $\mathrm{k}$ : standard selection differential at $5 \%$ selection intensity $(\mathrm{k}=2.063)$ and $\mathrm{X}$ : grand mean of trait $\mathrm{X}$.

Phenotypic and genotypic correlation coefficients $r_{p}$ and $r_{g}$ between particular pairs of traits A and B are defined as [24]:

$$
\begin{aligned}
& r_{p}=\operatorname{Cov}_{p}(A, B) /\left(\sigma_{p A} \times \sigma_{p B}\right) \\
& r_{g}=\operatorname{Cov}_{g}(A, B) /\left(\sigma_{g A} \times \sigma_{g B}\right)
\end{aligned}
$$

where $\operatorname{Cov}_{\mathrm{p}}$ and $\mathrm{Cov}_{\mathrm{g}}$ are phenotypic and genotypic covariances, respectively.

Phenotypic correlations between traits were determined following the Pearson correlation coefficient calculated from means of observed traits for each cane genotype [25].

Genetic improvement in cane and sugar yields may be achieved by targeting traits closely associated to them. A number of attributes have been proposed as indirect selection criteria for genetic improvement of yields in plant breeding programs [26-27]. Heritability represents the relative importance of genetic and environment factors in the expression of phenotypic and genotypic differences among genotypes within a population [28-30]. Consequently, the knowledge of heritability related to important traits and the correlations among them are key issues to determine the best selection strategy [31-32]. Genotypic coefficient of variation (GCV) is another measure of relative genetic variation of a trait within a population [33]. Chaudhary [34] reported high GCV for single stalk weight and millable cane number per unit area. Genotype x environment interactions $(\mathrm{GxE})$ are a serious concern in breeding programs as they affect selection decisions. When a rank of a genotype changes across environments, it requires evaluation of genotypes across environments to determine their real value [35]. Studies in various sugarcane breeding programs have reported significant $G \times E$ interactions for cane and sugar yields [3637].

\subsection{Statistical Analyses}

The quantitative data recorded in this study were subjected to the analysis of variance using statistical procedures described by Gomez and Gomez [38] and reported by Shitahum et al [39] with the assistance of R software package version 3.5.1 (Table 1). Differences between means of treatments were determined from Duncan test.

Table 1. Analysis of variance calculations regarding a $R C B D$.

\begin{tabular}{llll}
\hline $\begin{array}{l}\text { Source of } \\
\text { variation }\end{array}$ & $\begin{array}{l}\text { Degree of } \\
\text { freedom }\end{array}$ & Mean square & $\begin{array}{l}\text { Expected mean } \\
\text { square }\end{array}$ \\
\hline Replication & $\mathrm{r}-1$ & $\mathrm{MSr}$ & $\sigma_{\mathrm{e}}^{2}+\mathrm{g} \sigma_{\mathrm{r}}^{2}$ \\
Genotypes & $\mathrm{g}-1$ & $\mathrm{MSg}$ & $\sigma_{\mathrm{e}}^{2}+\mathrm{r}_{\mathrm{g}}^{2}$ \\
Error & $(\mathrm{r}-1)(\mathrm{g}-1)$ & $\mathrm{MSe}$ & $\sigma_{\mathrm{e}}^{2}$ \\
\hline
\end{tabular}

$\mathrm{R}$ : number of replicates; $\mathrm{g}=$ number of genotypes; MSr mean square due to replicates; $\mathrm{MSg}=$ mean square due to genotypes; MSe mean square of error; $\sigma_{\mathrm{g}}^{2}, \sigma_{\mathrm{r}}^{2}$, and $\sigma_{\mathrm{e}}^{2}$ stand for variances due to genotypes, replicates and error respectively. 


\section{Results and Discussion}

\subsection{Climatic Conditions Over Plant and First Ratoon Crops}

Total amount of rainfall recorded in first ratoon increased by $37.5 \%$ compared to that of plant cane (Figure 1). In absolute values, it varied from 991.4 to $1363.1 \mathrm{~mm}$, respectively. In contrast, variations of reference evaporation (ETo) and average daily air temperatures were almost negligible from one crop cycle to the other, with -0.7 and $1.4 \%$ respectively. In absolute values, total ETo varied on average from 1317.3 to $1308.2 \mathrm{~mm}$, whereas the average daily temperature from 28.1 to $27.7^{\circ} \mathrm{C}$. Lower total ETo and mean daily temperature obtained in first ratoon were explained by higher total rainfall recorded compared to that of plant crop. Total water deficit over the dry season (from November to June or July depending on the year) to be fulfilled with irrigation water gave $560 \mathrm{~mm}$ in plant cane and $320 \mathrm{~mm}$ in first ratoon.

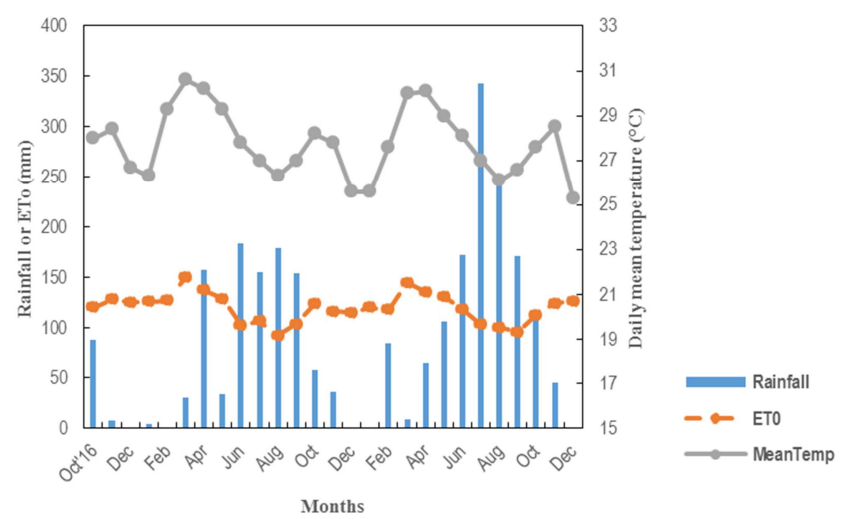

Figure 1. Prevailing climate of the experimental site over crop cycle (plant and 1rst ratoon crops) in Ferké 2, Ivory Coast.

\subsection{Multivariate Analyses}

It came out from the principal component analysis (Figure 2, Table 2) that most relevant traits in genotype clustering were related to juice quality (recoverable sucrose, sucrose content, purity), yields and yield components (millable stalk number/ha, stalk height, stalk diameter, internode number). Particularly, variety KQ228 from cluster 8 performed better juice quality and higher sugar yield, while R93-0214 from cluster 2 was the least productive with higher fiber content and lower millable stalk number, higher stalk weight and higher stalk diameter. The dendrogram deduced from hierarchical ascendant classification analysis (Figure 3) exhibits 8 different cluster genotypes which average agromorphological characteristics are shown in Table 3.

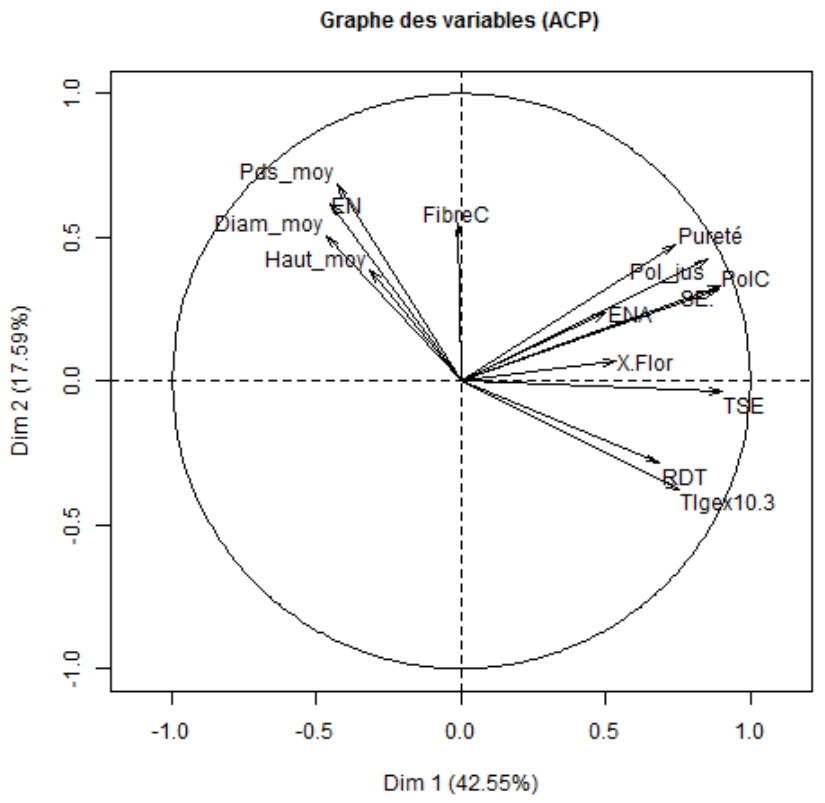

2a: Correlation circle of agronomic traits investigated in 1-2 factor plane.

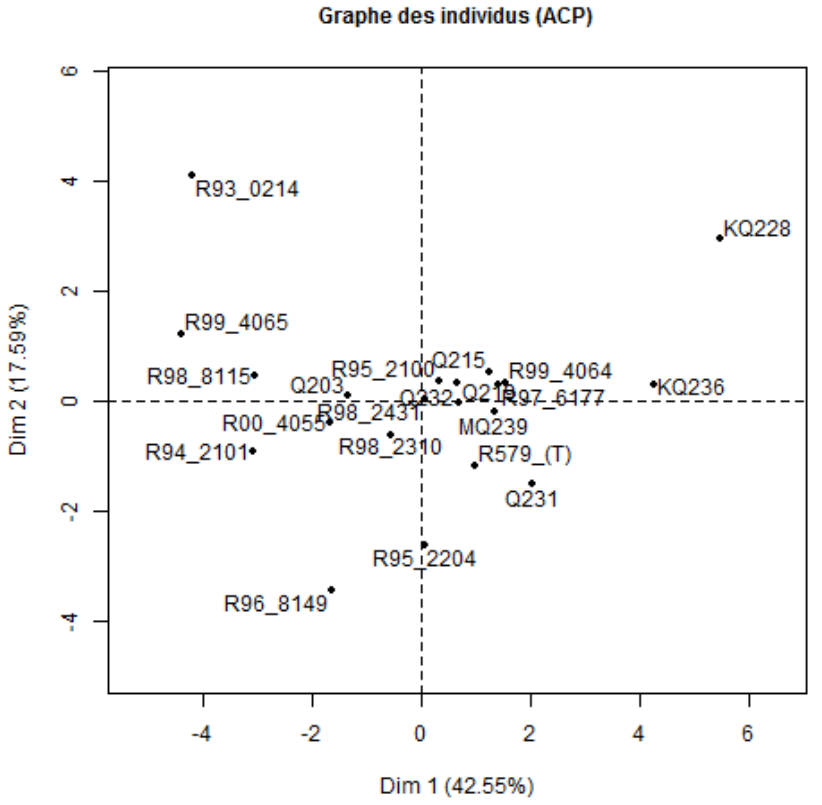

2b: Projection of sugarcane genotypes in 1-2 factor plane.

Figure 2. Results of Principal Component Analysis regarding aggregate data of both plant and first ratoon crops.

Table 2. Sugarcane cluster genotypes determined and their main agro-morphological characteristics (aggregate data of both plant and first ratoon crops).

\begin{tabular}{|c|c|c|}
\hline Clusters & Genotypes & Main characteristics \\
\hline $\mathrm{C} 1(\mathrm{n}=1)$ & R99-4065 & Lower juice quality, very high stalk height, higher internode number, high stalk weight \\
\hline $\mathrm{C} 2(\mathrm{n}=1)$ & R93-0214 & $\begin{array}{l}\text { Lower juice quality, lower stalk number/ha, higher stalk weight, lower cane and sugar yields, larger } \\
\text { stalk diameter, higher fiber content }\end{array}$ \\
\hline $\mathrm{C} 4(\mathrm{n}=2)$ & R99-2204, R96-8149 & Lower stalk height, lower internode number, lower height \\
\hline C5 $(n=2)$ & Q232, R00-4055 & Lower juice quality, higher stalk, higher internode number \\
\hline C6 $(n=6)$ & $\begin{array}{l}\text { Q215, R579, R95-2100, R97- } \\
\text { 6177, R98-2310, R98-2431 }\end{array}$ & $\begin{array}{l}\text { Higher cane and sugar yields, moderate height, moderate juice quality, lower to moderate fiber } \\
\text { content }\end{array}$ \\
\hline
\end{tabular}




\begin{tabular}{lll}
\hline Clusters & Genotypes & Main characteristics \\
\hline $\mathrm{C} 7(\mathrm{n}=4)$ & MQ239, Q219, Q231, R99-4064 & $\begin{array}{l}\text { Higher juice quality, Higher stalk number/ha, higher cane and sugar yields, taller stalk, higher fiber } \\
\text { content } \\
\text { Very High juice quality, higher cane and sugar yields, higher flowering rate, higher stem borer } \\
\text { infestation }\end{array}$ \\
\hline
\end{tabular}

Table 3. Mean values of clusters genotypes determined following different agronomic traits investigated in Ferké 2, Ivory Coast (aggregate data of both plant and first ratoon crops).

\begin{tabular}{|c|c|c|c|c|c|c|c|c|}
\hline \multirow{2}{*}{$\begin{array}{l}\text { Agronomic } \\
\text { traits }\end{array}$} & \multicolumn{8}{|c|}{ Different cluster genotypes } \\
\hline & C1 & $\mathrm{C2}$ & C3 & C4 & $\mathbf{C 5}$ & C6 & C7 & C8 \\
\hline Pol juice & 15,7 & 17,2 & 16,1 & 16,4 & 16,7 & 17,2 & 17,6 & 19,6 \\
\hline Purity & 86,8 & 89,8 & 88,7 & 87,8 & 88,3 & 89,8 & 90,1 & 92,3 \\
\hline $\mathrm{Pol} \% \mathrm{C}$ & 12,7 & 13,5 & 13,2 & 13,4 & 13,4 & 14,1 & 14,2 & 15,9 \\
\hline Fiber $\%$ & 13,7 & 15,5 & 13,0 & 13,0 & 14,4 & 13,0 & 14,3 & 13,7 \\
\hline CYield & 135,5 & 95,0 & 124,2 & 137,2 & 149,9 & 155,1 & 152,7 & 150,4 \\
\hline RSucrose & 9,0 & 9,8 & 9,6 & 9,7 & 9,6 & 10,4 & 10,4 & 12,0 \\
\hline SYield & 12,1 & 9,3 & 11,8 & 13,3 & 14,4 & 16,1 & 15,8 & 18,1 \\
\hline SNbx103 & 104,3 & 73,7 & 99,8 & 114,8 & 112,7 & 114,4 & 129,7 & 125,2 \\
\hline$\% \mathrm{BIN}$ & 6,6 & 6,7 & 8,2 & 5,0 & 9,3 & 7,9 & 8,1 & 11,3 \\
\hline AvWeight & 1,6 & 1,6 & 1,4 & 1,2 & 1,4 & 1,4 & 1,2 & 1,3 \\
\hline AvDiam & 22,1 & 25,5 & 24,3 & 21,4 & 21,9 & 23,3 & 21,3 & 22,0 \\
\hline AvHeight & 3,9 & 3,1 & 2,9 & 2,8 & 3,3 & 3,0 & 3,1 & 2,9 \\
\hline NbInternode & 30,3 & 28,2 & 24,2 & 20,5 & 24,3 & 23,0 & 24,2 & 22,7 \\
\hline Flowering & 5,3 & 9,0 & 18,8 & 25,0 & 57,8 & 32,1 & 24,3 & 57,4 \\
\hline
\end{tabular}

\section{Cluster Dendrogram}

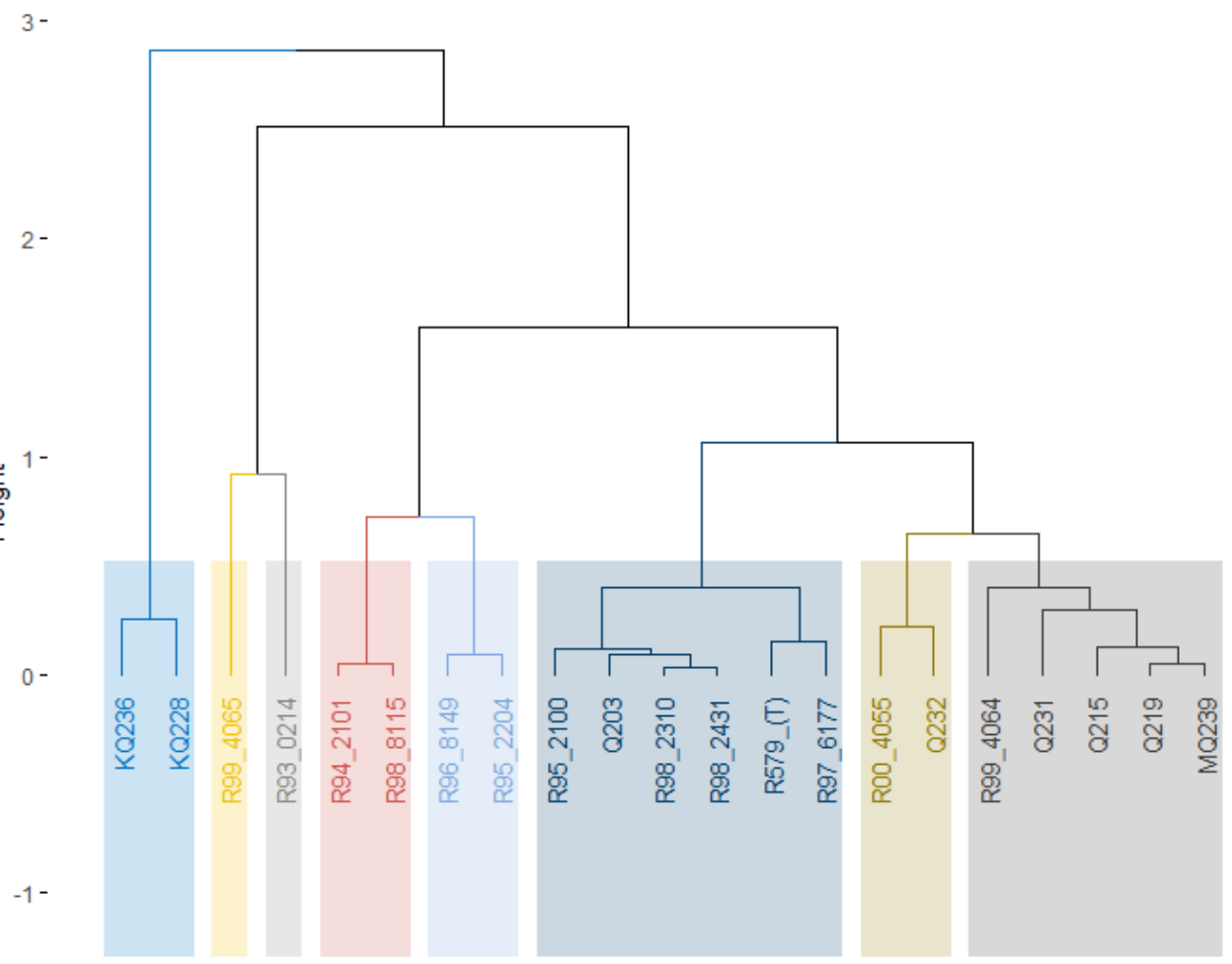

Figure 3. Dendrogram deduced from cluster analysis of all 21 sugarcane genotypes tested in Ferké (Ivory Coast), the check variety (R579) included (aggregate data of both plant and first ratoon crops).

\subsection{Performance of Cane Genotypes Tested}

Except for the average stalk weight with significant differences within genotypes $(\mathrm{P}<0.05)$, highly significant differences $(\mathrm{P}<0.01)$ were observed for all agromorphological traits investigated (Table 4). Based on sugar yields, three genotypes, namely KQ228, R97-6177 and R994064 were equivalent to the check variety R579 with respectively $19.2,17.7$ and $17.3 \mathrm{t}$ sugar/ha. Their cane yield performances ranged from 153 to $170.8 \mathrm{t} / \mathrm{ha}$ compared to 170.7 for the check. Although a relatively high level of stem borer infestation recorded on KQ 228 and KQ236 genotypes, with respectively 10 and $12 \% \mathrm{BIN}$ due to high rate of nitrogen fertilizer applied in plant cane, their sucrose content were kept high (16.5 and $15.3 \mathrm{Pol} \% \mathrm{C})$. The later genotype KQ236 which gave $16.9 \mathrm{t}$ sugar/ha was equivalent to one of 
the promising one indicated previously (R99-4064).

Table 4. Mean values of agronomic traits regarding plant and first ratoon crops on aggregate for different sugarcane genotypes tested in Ferké 2, Ivory Coast.

\begin{tabular}{|c|c|c|c|c|c|c|c|}
\hline Genotypes & Pol juic \% & Purity \% & Pol\%C & Fiber \%C & CYield (t/ha) & RSucrose \%C & SYield (t/ha) \\
\hline KQ228 & 20.9 & $92.9 \mathrm{f}$ & $16.5 \mathrm{c}$ & $14.0 \mathrm{bc}$ & $153.1 \mathrm{f}$ & $12.5 \mathrm{c}$ & $19.2 \mathrm{j}$ \\
\hline KQ236 & 19.9 & $91.7 \mathrm{e}$ & $15.3 \mathrm{~b}$ & $13.4 \mathrm{~b}$ & $147.7 \mathrm{f}$ & $11.5 \mathrm{c}$ & $16.9 \mathrm{gh}$ \\
\hline MQ239 & 18.0 & $89.9 \mathrm{de}$ & $14.4 \mathrm{ab}$ & $14.2 \mathrm{c}$ & $144.5 \mathrm{e}$ & $10.5 \mathrm{~b}$ & $15.1 \mathrm{f}$ \\
\hline Q203 & 18.2 & $87.9 b c$ & 13.9ab & $12.8 \mathrm{ab}$ & $125.8 \mathrm{bc}$ & $10.1 \mathrm{ab}$ & $12.5 \mathrm{c}$ \\
\hline Q215 & 19.1 & $90.4 \mathrm{de}$ & $14.7 \mathrm{ab}$ & $13.2 \mathrm{~b}$ & $142.2 \mathrm{de}$ & $10.9 b c$ & $15.4 \mathrm{fg}$ \\
\hline Q219 & 17.5 & $89.9 \mathrm{de}$ & 14.1ab & $14.0 \mathrm{c}$ & $150.1 \mathrm{f}$ & $10.4 \mathrm{~b}$ & $15.5 \mathrm{fg}$ \\
\hline Q231 & 17.2 & $89.9 \mathrm{de}$ & $13.9 \mathrm{ab}$ & $14.0 \mathrm{c}$ & $151.2 \mathrm{f}$ & $10.2 \mathrm{~b}$ & $15.3 \mathrm{fg}$ \\
\hline Q232 & 17.5 & $89.6 \mathrm{~d}$ & $13.5 \mathrm{ab}$ & $14.3 \mathrm{c}$ & $156.8 \mathrm{~g}$ & $9.8 \mathrm{ab}$ & $15.4 \mathrm{fg}$ \\
\hline R00-4055 & 17.8 & $87.0 \mathrm{~b}$ & $13.2 \mathrm{a}$ & $14.5 \mathrm{~cd}$ & $143.0 \mathrm{e}$ & $9.4 \mathrm{ab}$ & $13.4 \mathrm{~cd}$ \\
\hline R579 & 18.1 & $88.7 \mathrm{bc}$ & $14.3 \mathrm{ab}$ & $12.5 \mathrm{a}$ & 170.7hi & $10.5 \mathrm{~b}$ & $17.9 \mathrm{ij}$ \\
\hline R93-0214 & 17.5 & $89.8 \mathrm{de}$ & $13.5 \mathrm{ab}$ & $15.5 \mathrm{e}$ & $95.0 \mathrm{a}$ & $9.8 \mathrm{ab}$ & $9.3 \mathrm{a}$ \\
\hline R94-2101 & 15.7 & $88.5 b c$ & $12.7 \mathrm{a}$ & $12.9 \mathrm{ab}$ & $127.6 \mathrm{c}$ & $9.2 \mathrm{ab}$ & $11.7 \mathrm{bc}$ \\
\hline R95-2100 & 18.0 & $89.4 \mathrm{~cd}$ & $13.9 \mathrm{ab}$ & $13.4 \mathrm{~b}$ & $150.5 \mathrm{f}$ & $10.2 \mathrm{~b}$ & $15.2 \mathrm{fg}$ \\
\hline R95-2204 & 18.1 & $89.1 \mathrm{~cd}$ & $13.7 \mathrm{ab}$ & $13.1 \mathrm{~b}$ & 139.6de & $10.0 \mathrm{ab}$ & $13.9 \mathrm{~d}$ \\
\hline R96-8149 & 17.0 & $86.4 \mathrm{a}$ & $13.2 \mathrm{a}$ & $12.9 \mathrm{ab}$ & $134.7 \mathrm{~d}$ & 9.4ab & $12.7 \mathrm{c}$ \\
\hline R97-6177 & 17.7 & $90.7 \mathrm{de}$ & $14.0 \mathrm{ab}$ & $13.1 \mathrm{~b}$ & $170.8 \mathrm{hi}$ & $10.4 \mathrm{~b}$ & $17.7 \mathrm{i}$ \\
\hline R98-2310 & 16.9 & $88.8 \mathrm{c}$ & $13.8 \mathrm{ab}$ & $12.8 \mathrm{ab}$ & $145.5 \mathrm{ef}$ & $10.1 \mathrm{~b}$ & $14.7 \mathrm{e}$ \\
\hline R98-2431 & 16.2 & $90.5 \mathrm{de}$ & $13.8 \mathrm{ab}$ & $12.9 \mathrm{ab}$ & $151.1 \mathrm{f}$ & $10.2 \mathrm{~b}$ & $15.6 \mathrm{fg}$ \\
\hline R98-8115 & 16.4 & $89.7 \mathrm{de}$ & $13.0 \mathrm{a}$ & $13.2 \mathrm{~b}$ & $119.3 \mathrm{~b}$ & $9.5 \mathrm{ab}$ & $11.2 \mathrm{~b}$ \\
\hline R99-4064 & 18.8 & $90.7 \mathrm{de}$ & $14.3 \mathrm{ab}$ & $14.9 \mathrm{de}$ & $165.2 \mathrm{~h}$ & $10.5 \mathrm{~b}$ & $17.3 \mathrm{hi}$ \\
\hline R99-4065 & 17.0 & $86.8 \mathrm{ab}$ & $12.7 \mathrm{a}$ & $13.7 b c$ & $135.5 \mathrm{~d}$ & $9.0 \mathrm{a}$ & $12.1 \mathrm{bc}$ \\
\hline Mean & 17.1 & 89.4 & 13.9 & 13.6 & 143.8 & 102 & 14.7 \\
\hline CV (\%) & 6.6 & 1.7 & 6.7 & 5.0 & 12.1 & 8.2 & 14.2 \\
\hline Replications & $* *$ & $* * *$ & $* *$ & Ns & Ns & $* * *$ & Ns \\
\hline Genotypes & $* * *$ & $* * *$ & $* * *$ & $* * *$ & $* * *$ & $* * *$ & $* * *$ \\
\hline Crop cycles & $* *$ & $* * *$ & $* * *$ & $* * *$ & $* * *$ & $* * *$ & ns \\
\hline
\end{tabular}

Table 4. Continued.

\begin{tabular}{|c|c|c|c|c|c|c|c|}
\hline Genotypes & SNbx103 (/ha) & BIN (\%) & AvWeight (kg) & AvDiam (mm) & AvHeight (m) & NbInternode (-) & Flowering (\%) \\
\hline KQ228 & $117.5 \mathrm{e}$ & $10.2 \mathrm{~b}$ & 1.4 & 22.8 & 2.9 & 23.5 & 61.8 \\
\hline KQ236 & $132.8 \mathrm{~g}$ & $12.4 \mathrm{c}$ & 1.3 & 21.2 & 2.9 & 22.0 & 53.0 \\
\hline MQ239 & $118.8 \mathrm{f}$ & $8.2 \mathrm{~b}$ & 1.2 & 21.2 & 3.2 & 22.7 & 34.5 \\
\hline Q215 & $113.0 \mathrm{~d}$ & $8.7 \mathrm{~b}$ & 1.3 & 23.0 & 3.0 & 23.7 & 29.2 \\
\hline Q219 & $123.5 \mathrm{f}$ & $6.1 \mathrm{ab}$ & 1.3 & 22.1 & 3.2 & 24.2 & 28.2 \\
\hline Q231 & $137.5 \mathrm{gh}$ & $12.4 \mathrm{c}$ & 1.1 & 20.5 & 2.9 & 24.2 & 34.5 \\
\hline R00-4055 & $109.3 \mathrm{~cd}$ & $8.0 \mathrm{~b}$ & 1.4 & 22.1 & 3.3 & 24.3 & 36.0 \\
\hline R579 & $125.3 \mathrm{f}$ & $6.9 \mathrm{ab}$ & 1.5 & 22.9 & 2.9 & 22.3 & 0.0 \\
\hline R93-0214 & $73.7 \mathrm{a}$ & $6.7 \mathrm{ab}$ & 1.6 & 25.5 & 3.1 & 28.2 & 9.0 \\
\hline R94-2101 & $92.7 \mathrm{~b}$ & $7.2 \mathrm{ab}$ & 1.3 & 24.1 & 2.9 & 24.5 & 22.5 \\
\hline R95-2100 & $107.3 \mathrm{~cd}$ & $10.0 \mathrm{~b}$ & 1.5 & 23.5 & 3.1 & 21.3 & 52.0 \\
\hline R95-2204 & $114.5 \mathrm{de}$ & $5.1 \mathrm{a}$ & 1.2 & 20.9 & 2.8 & 20.3 & 25.7 \\
\hline R96-8149 & $115.2 \mathrm{de}$ & $5.0 \mathrm{a}$ & 1.2 & 21.8 & 2.8 & 20.8 & 24.3 \\
\hline R97-6177 & $127.5 \mathrm{fg}$ & $7.5 \mathrm{~b}$ & 1.4 & 24.0 & 3.1 & 24.0 & 52.5 \\
\hline R98-2431 & $110.0 \mathrm{~cd}$ & $8.5 b$ & 1.4 & 23.2 & 3.0 & 24.8 & 16.3 \\
\hline R98-8115 & $95.8 \mathrm{bc}$ & $8.0 \mathrm{~b}$ & 1.5 & 24.5 & 3.0 & 23.5 & 8.8 \\
\hline R99-4064 & $138.8 \mathrm{~h}$ & $5.6 \mathrm{ab}$ & 1.3 & 21.5 & 3.2 & 26.2 & 0.0 \\
\hline R99-4065 & $104.3 \mathrm{c}$ & $6.6 \mathrm{ab}$ & 1.6 & 22.1 & 3.9 & 30.3 & 5.3 \\
\hline Mean & 113.7 & 8.0 & 1.4 & 22.7 & 3.1 & 23.9 & 30.5 \\
\hline CV (\%) & 11.8 & 34.8 & 17.3 & 8.2 & 7.5 & 10.6 & 59.1 \\
\hline Replications & $* * *$ & Ns & $* *$ & Ns & Ns & Ns & Ns \\
\hline Genotypes & $* * *$ & $* * *$ & $*$ & $* * *$ & $* * *$ & $* * *$ & $* * *$ \\
\hline Crop cycles & $* *$ & $* * *$ & $* * *$ & ns & $* * *$ & $* * *$ & $* * *$ \\
\hline
\end{tabular}

SNb: millable stalk number/ha; BIN: bored internode; AvWeight: average stalk weight; AvHeight: average stalk height; ns: non-significant.

$*, * *, * * *$ : significant at 5,1 and $0.1 \%$ levels of probability.

\subsection{Phenotypic Correlations Between Pairs of Agro-morphological Traits}

All juice quality traits (pol juice, purity, sucrose content, and recoverable sucrose) were positively, strongly and highly significantly correlated between pairs with coefficients ranging from 0.83 to 0.99 . Similar correlation was obtained with cane and sugar yields which coefficient $\left(0.83^{* * *}\right)$ 
matches that magnitude. All juice quality traits were also positively, moderately and highly significantly correlated to sugar yield with coefficients ranging from 0.51 to 0.60 . In contrast, they were loosely correlated and mostly not significantly $(\mathrm{P}=0.05)$ to cane yield with coefficients ranging from 0.01 to 0.06 . The millable stalk number per hectare was positively and moderately correlated to cane and sugar yields, with 0.56 and $0.58^{* * *}$, respectively, as coefficients. Agro-morphological characters like stalk diameter and stalk height were moderately and significantly correlated to stalk weight with coefficients of 0.72 and 0.60 , respectively. Sugarcane flowering impacted negatively on stalk internode number as exhibited by a correlation coefficient of $-0.32 * * *$, while it enhanced cane and sugar yields with values of $0.28^{* * *}$ and $0.27 * * *$ respectively. The cane fiber content was correlated positively to internode number $(0.42 * * *)$ and stem borer infestations rate $\left(0.30^{* * *}\right)$, but negatively to cane yield $\left(0.21^{* * *}\right)$ as reported by different investigators [5, 4041]. More importantly, it was not negatively correlated to the recoverable sucrose in contrast of findings obtained in the same agro-ecological context [42].

\subsection{Genotypic Correlations Between Pairs of Agro-morphological Traits}

Juice quality and sugar yield traits were positively and strongly correlated between pairs with coefficients ranging from 0.86 to 0.98 . Similar correlation was observed not only with cane and sugar yields $(\mathrm{r}=0.96)$, but also between sugar yield other characters like sucrose content $(0.82)$, recoverable sucrose (0.85), and millable stalk number per plot (0.85). Such strong and positive genotypic correlation was observed also between millable stalk number per plot and traits like cane and sugar yields ( $\mathrm{r}=0.89$ and 0.85 respectively). It was still observed, on the one hand, between the number of internodes and single stalk weight and height $(\mathrm{r}=0.75$ and 0.81 respectively), and on the other hand, between single stalk weight and height (0.98). In contrast, strong negative correlation was observed between millable stalk number per plot and single stalk weight and diameter $(\mathrm{r}=-0.84$ and -0.83 respectively). As reported by several researchers [30, 43], such strong and positive genotypic correlations indicate that selection based on single stalk weight, internode number and millable stalk number could lead to improvement in agromorphological traits like stalk diameter, stalk height and yield traits. The flowering ability was negatively correlated moderately or loosely with agro-morphological traits like stalk number of internodes (-0.42), stalk weight $(-0.22)$, stalk diameter (-0.23) and stalk height (-0.06). In contrast, this character was positively and moderately or loosely correlated with stem borer infestation rate $(0.67)$, juice quality traits $(\mathrm{r}=0.38-0.44)$, cane and sugar yields $(\mathrm{r}=0.34$ and 0.43 respectively), and millable stalk number per plot (0.23).

Table 5. Phenotypic and genotypic correlation matrix of agro-morphological traits investigated (respectively below and above diagonal) regarding aggregate data of both plant and first ratoon crops.

\begin{tabular}{|c|c|c|c|c|c|c|c|}
\hline Genotypes & Pol juice & Purity & Pol\%C & Fiber\% & CYield & RSucrose & SYield \\
\hline Pol juice & 1.00 & 0.89 & 0.98 & 0.28 & 0.39 & 0.98 & 0.77 \\
\hline Purity & $0.83 * * *$ & 1.00 & 0.86 & 0.21 & 0.34 & 0.92 & 0.66 \\
\hline $\mathrm{Pol} \% \mathrm{C}$ & $0.98 * * *$ & $0.83 * * *$ & 1.00 & 0.07 & 0.45 & 0.98 & 0.82 \\
\hline Fiber $\%$ & $0.36 * * *$ & $0.27 * * *$ & 0.17 & 1.00 & -0.20 & 0.05 & -0.12 \\
\hline CYield & 0.01 & 0.03 & 0.05 & $-0.21^{*}$ & 1.00 & 0.45 & 0.96 \\
\hline RSucrose & $0.97 * * *$ & $0.87 * * *$ & $0.99 * * *$ & 0.14 & $0.06^{* * *}$ & 1.00 & 0.82 \\
\hline SYield & $0.54 * * *$ & $0.51 * * *$ & $0.59 * * *$ & -0.09 & $0.83 * * *$ & $0.60 * * *$ & 1.00 \\
\hline$\% \mathrm{BIN}$ & $0.21^{*}$ & $0.23 * * *$ & 0.16 & $0.30 * * *$ & -0.04 & 0.16 & 0.06 \\
\hline AvWeight & $-0.31 * *$ & $-0.27 * * *$ & $-0.32 * * *$ & -0.08 & 0.20 & $-0.31 * * *$ & -0.01 \\
\hline AvDiam & $-0.27 * *$ & -0.17 & $-0.28 * * *$ & -0.05 & -0.16 & $-0.27 * * *$ & $-0.26 * * *$ \\
\hline AvHeight & $-0.26 * * *$ & $-0.30 * * *$ & $-0.29 * * *$ & 0.07 & $0.28 * * *$ & $-0.30 * * *$ & 0.05 \\
\hline NbInternode & 0.04 & 0.05 & -0.04 & $0.42 * * *$ & $-0.23 * * *$ & -0.05 & -0.21 \\
\hline Flowering & 0.05 & 0.11 & 0.08 & -0.12 & $0.28^{* * *}$ & 0.10 & $0.27 * * *$ \\
\hline
\end{tabular}

Table 5. Continued.

\begin{tabular}{|c|c|c|c|c|c|c|c|}
\hline Genotypes & SNbx103 & $\%$ BIN & AvWeight & AvDiam & AvHeight & NbInternode & Flowering \\
\hline Pol juice & 0.49 & 0.49 & -0.20 & -0.24 & -0.20 & -0.19 & 0.43 \\
\hline Purity & 0.35 & 0.53 & -0.05 & 0.00 & -0.26 & -0.12 & 0.38 \\
\hline $\mathrm{Pol} \% \mathrm{C}$ & 0.52 & 0.49 & -0.23 & -0.22 & -0.31 & -0.32 & 0.43 \\
\hline Fiber $\%$ & -0.06 & 0.09 & 0.08 & -0.14 & 0.42 & 0.52 & 0.05 \\
\hline CYield & 0.89 & 0.17 & -0.38 & -0.55 & 0.06 & -0.33 & 0.34 \\
\hline RSucrose & 0.51 & 0.51 & -0.21 & -0.19 & -0.33 & -0.32 & 0.44 \\
\hline SYield & 0.85 & 0.34 & -0.35 & -0.45 & -0.12 & -0.37 & 0.43 \\
\hline SNbx103 & 1.00 & 0.34 & -0.84 & -0.83 & -0.10 & -0.34 & 0.23 \\
\hline$\% \mathrm{BIN}$ & $0.21 *$ & 1.00 & -0.15 & -0.20 & -0.15 & -0.06 & 0.67 \\
\hline AvWeight & $-0.19 *$ & -0.14 & 1.00 & 0.98 & 0.67 & 0.75 & -0.22 \\
\hline AvDiam & $-0.37 * *$ & -0.04 & $0.72 * * *$ & 1.00 & -0.08 & 0.33 & -0.23 \\
\hline AvHeight & -0.03 & $-0.21 *$ & $0.60 * * *$ & 0.24 & 1.00 & 0.81 & -0.06 \\
\hline NbInternode & -0.07 & $0.21 *$ & $0.34 * * *$ & $0.37 * * *$ & 0.44 & 1.00 & -0.42 \\
\hline Flowering & 0.03 & 0.02 & 0.03 & -0.10 & 0.04 & $-0.32 * * *$ & 1.00 \\
\hline
\end{tabular}




\subsection{Phenotypic and Genotypic Coefficient of Variation (PCV, GCV)}

As stated by Shivasubramanian and Menon [43] cited by different investigators [18, 25, 44-45], PCV and GCV values are ranked as low, medium and high with 0 to $10 \%, 11$ to $20 \%$ and higher than $20 \%$ respectively (Table 5). Based on that statement, all PCV and GCV values determined which ranged from 2.0 to $77.6 \%$ on the one hand, and from 1.6 to $664.1 \%$ on the other hand, varied from low to high. As reported by different authors [46-47], high GCV and PCV indicated that selection might be effective on traits investigated and their expression be relevant to the genotypic potential. Particularly, agronomic traits exhibiting relatively high GCV estimates like flowering ability, stem borer infestations and sugar yield with values ranging from 16 to $64 \%$, might respond favorably to selection [30]. Regardless the trait considered in this study, the phenotypic coefficient of variation was higher than the genotypic one suggesting that apparent variations were not only due to genetics but also to environmental influences. However, differences between PCV and GCV for most traits were small in line of observations made by different investigators [25, 48-49], indicating high prospects for genetic progress through selection under conditions of this study.

\subsection{Phenotypic, Genotypic and Environmental Variance}

Regardless the trait considered, phenotypic variance data obtained were higher than the genotypic ones. This shows a greater influence of environment on genetic variations in line of observations made by different authors [18, 30, 43]. Moreover, except stalk borer infestation rate and single stalk weight, genotypic variance data calculated were higher than environmental ones suggesting important variations among genotypes in line of their higher or moderate values of broad sense heritability $\left(\mathrm{h}^{2} \geq 53 \%\right)$ ranging from 53.6 to $100 \%$. Therefore, agro-morphological traits with lower genotypic variance data like stalk borer infestation rate and single stalk weight suggested limited variations among genotypes and exhibited lower or moderate heritability values of 47.6 and $26.8 \%$ respectively.

\subsection{Heritability and Genetic Advance}

Estimates of broad-sense heritability $\left(\mathrm{h}^{2}\right)$ are categorized according to Robinson [50] cited by different authors [18, 41, $43]$ as low $(<30 \%)$, moderate $(30 \leq-<60 \%)$ or high $(\geq 60 \%)$. Higher heritability values ranging from 60.6 to $100 \%$ were observed on traits like flowering rate, millable stalk number, cane yield and sugar yields, fiber content, internode number, single stalk weight and juice quality (Pol juice, purity, sucrose content) - (Table 6). In contrast, moderate values (47.6 - 53.6\%) were observed for stem borer infestation rate and stalk diameter. The lowest value of heritability was obtained on single stalk weight $(26.8 \%)$. Estimates of mean genetic advance (GAM) are categorized similarly to GCV and PGV according to Falconer and Mackay [24] cited by several authors [43-44, 48-50]. Therefore, higher values of genetic advance were observed for flowering rate (109.2\%), sugar yield $(29.0 \%)$, millable stalk number $(21.0 \%)$ and stem borer infestation rate $(33.3 \%)$. Moderate values were recorded on number of internodes $(14.1 \%)$, fiber content $(11.7 \%)$, recoverable sucrose $(12.5 \%)$ and single stalk height (12.1), while lower values on traits like juice quality $(2.7-$ $10.0 \%)$, single stalk weight $(7.4 \%)$, and stalk diameter (7.8\%). Higher values of GAM suggest that a significant proportion of the total variance might be heritable and selection of corresponding traits would be effective. Similar values were reported by several authors in sugarcane on single stalk weight $[30,51-52]$. As indicated by Vidya et al [53], knowledge of variability and heritability of characters is essential for identifying those relevant to genetic improvement through selection. Moreover, the effectiveness of selection will depend not only on heritability but also on genetic advance [54-55].

Higher levels of mean genetic advance observed for cane and sugar yields, millable stalk number, stem borer infestation rate and flowering rate were the result of moderate or high broad sense heritability combined with high GCV for these traits in line of findings reported by Bakshi [56]. According to this author, heritability estimates together with expected genetic gain were more useful than heritability values alone in predicting the effects of selecting best genotypes. Chaudhary [34] also reported high heritability and genetic gain for single cane weight followed by number of millable cane in a study of 36 clones indicating substantial scope for cane yield improvement. On the other hand, sucrose content recorded low heritability and genetic gain suggesting little scope for improvement in this character [57]. Patel et al [58] also reported high heritability estimates for single cane weight, number of internodes, tiller number, hand refractrometer brix, cane diameter and millable cane length, which were associated with moderate to high genetic advance (23-190\%). Findings indicated that these characters might be improved through selection. From the literature, findings on heritability, genetic gain, PCV and GCV for the same traits look sometimes controversial depending on locations, crop cycle (plant cane or ratoon), soil types, water regime (rainfed or irrigated), etc. $[6,22,40,59]$. But still, this is all about the scope of experimentation in agronomy, findings being mostly site-specific.

Table 6. Variability and heritability among sugarcane genotypes tested in Ferké 2, Ivory Coast (aggregate data of both plant and first ratoon crops)

\begin{tabular}{|c|c|c|c|c|c|c|c|c|c|}
\hline \multirow{2}{*}{$\begin{array}{l}\text { Agronomic } \\
\text { traits }\end{array}$} & \multirow{2}{*}{ Mean } & \multicolumn{3}{|c|}{ Variance } & \multicolumn{2}{|c|}{ Coefficient of variation (\%) } & \multirow{2}{*}{$\mathrm{H}^{2}(\%)$} & \multirow{2}{*}{ GA (-) } & \multirow{2}{*}{ GAM (\%) } \\
\hline & & $\sigma^{2} \mathbf{e}$ & $\sigma^{2} \mathrm{~g}$ & $\sigma^{2} p$ & GCV & PCV & & & \\
\hline Pol juice & 17.1 & 0.54 & 1.04 & 1.59 & 5.96 & 7.35 & 65.8 & 1,71 & 10.0 \\
\hline Purity & 89.5 & 1.10 & 2.11 & 3.21 & 1.63 & 2.00 & 65.9 & 2.43 & 2.7 \\
\hline Pol $\%$ C & 13.9 & 0.29 & 0.65 & 0.95 & 5.81 & 6.99 & 68.9 & 1.38 & 9.9 \\
\hline Fiber\% & 13.59 & 0.00 & 0.60 & 0.60 & 5.69 & 5.69 & 100.0 & 1.60 & 11.7 \\
\hline
\end{tabular}




\begin{tabular}{|c|c|c|c|c|c|c|c|c|c|}
\hline \multirow{2}{*}{$\begin{array}{l}\text { Agronomic } \\
\text { traits }\end{array}$} & \multirow{2}{*}{ Mean } & \multicolumn{3}{|c|}{ Variance } & \multicolumn{2}{|c|}{ Coefficient of variation (\%) } & \multirow{2}{*}{$\mathbf{H}^{2}(\%)$} & \multirow{2}{*}{ GA (-) } & \multirow{2}{*}{ GAM (\%) } \\
\hline & & $\sigma^{2} \mathrm{e}$ & $\sigma^{2} g$ & $\sigma^{2} \mathbf{p}$ & GCV & PCV & & & \\
\hline CYield & 143.80 & 108.90 & 269.23 & 378.13 & 11.41 & 13.52 & 71.2 & 28.56 & 19.9 \\
\hline RSucrose & 10.20 & 0.23 & 0.54 & 0.78 & 7.23 & 8.64 & 69.9 & 1.27 & 12.5 \\
\hline SYield & 14.68 & 1.70 & 5.55 & 7.25 & 16.04 & 18.33 & 76.6 & 4.25 & 29.0 \\
\hline SNbx 103 & 113.71 & 100.00 & 201.40 & 301.40 & 12.48 & 15.27 & 66.8 & 23.93 & 21.0 \\
\hline$\% \mathrm{BIN}$ & 8.04 & 3.90 & 3.54 & 7.45 & 23.40 & 33.93 & 47.6 & 2,68 & 33.3 \\
\hline AvWeight & 1.37 & 0.02 & 0.01 & 0.03 & 6.93 & 13.39 & 26.8 & 0,10 & 7.4 \\
\hline AvHeight & 3.08 & 0.03 & 0.05 & 0.08 & 7.24 & 8,93 & 65.7 & 0,37 & 12.1 \\
\hline NbInternode & 23.86 & 2.87 & 4.42 & 7.29 & 8.81 & 11.31 & 60.6 & 3,38 & 14.1 \\
\hline Flowering & 30.52 & 178.60 & 383.03 & 561.63 & 64.12 & 77.64 & 68.2 & 33.34 & 109.2 \\
\hline
\end{tabular}

\section{Conclusions}

The study showed that most relevant traits in genotype clustering were related to juice quality (recoverable sucrose, sucrose content, purity), yields and yield components (millable stalk number/ha, stalk height, stalk diameter, internode number). Based on sugar yields, four genotypes equivalent to the check variety (R579), namely KQ228, R976177, R99-4064 and KQ236, were found promising for the next advanced selection stage with respectively 19.2, 17.7, 17.3 and $16.9 \mathrm{t}$ sugar/ha. Their cane yield performances ranged from 147.7 to 170.8 tha compared to 170.7 for the check and belong to three clusters genotypes over the eight determined. Not only sugar yield, but also flowering rate, stem borer infestation rate and number of tillers per hectare were found as the most relevant agro-morphological traits in the genetic variation of sugarcane genotypes tested.

\section{References}

[1] FAO, 2014. FAO STAT, FAO statistical databases. Available at: http://faostat3.fao.org/(Last accessed June 07, 2016.

[2] Jackson, P. A. (2005). Breeding for improved sugar content in sugarcane. Field Crops Res. 92 (2-3): 277-90.

[3] Tyagi S. D. and D. N. Singh (1998). Studies on genetic variability for stalk characters in sugarcane. Indian Sugar XL VIII: 259-62.

[4] Chaudhary, R. R. (2001). Genetic variability and heritability in sugarcane. Nepal Agric Res. 4 \& 5: 56-8.

[5] Béhou, Y. Y. M. and C. B. Péné (2019). Genetic variability and heritability among sugarcane genotypes in plant crop for some agronomic traits under tropical dry climate of Ferké, Ivory Coast. J. Exp. Agric. Int. 38 (1): 1-14.

[6] Péné, C. B., K. D. Kouamé, H. Dove and B. M. Boua (2016). Incidence des infestations du foreur de tiges Eldana saccharina W (Lepidoptera: Pyralidae) en culture irriguée de canne à sucre selon la variété et la période de récolte en Côte d'Ivoire. J. Appl. Biosci. 102: 9687-9698.

[7] Bakhsh, A., M. Arshad and A. M. Haqqan (2006). Effect of GxE interaction on relationship between grain yield and its components in chickpea (Cicer arietinum L). Pakistan J. Bot. 38: 683-90.

[8] Da Silva, F. F., M. G. Pereira, H. C. C. Ramos, Jr.
Damasceno, N. S. Pereira and C. D. Ide (2007). Genotypic correlations of morpho-agronomic traits in papayas and implications for genetic breeding. Crop Breed. Appl. Biotech 7: $345-52$.

[9] Tena, E., A. Ayana and F. Mekbib (2016). Heritability and correlation among sugarcane (Saccharum spp.) yields and some agronomic and sugar quality traits in Ethiopia. Am. J. Pant Sci. 7 (10): 1453-77.

[10] Jackson, P. (1994). Genetic relationships between attributes in sugarcane clones closely related to Saccharum spontaneum. Euphytica 79: 101-8.

[11] Tyagi S. D., M. H. Khan (2010). Studies on genetic variability and interrelationships among different traits in Microsperma Lentil (Lens culinaris Medik). J. Agric Biotech Sust. Dev 2: 15-20.

[12] De Sousa-Vierra O. and S. B. Milligan (2005). Interrelationships of cane yield components and their utility in sugarcane family selection: path coefficient analysis. Intersciencia 30: 93-9.

[13] Milligan, S. B., K. A. Gravois, K. P. Bischoff and F. A. Martin (1990). Crop effects on broad-sense heritability and genetic variances of sugarcane yield components. Crop Sci. 30: 34449.

[14] Gravois, K. A., S. B. Milligan and F. A. Martin (1991). Additive genetic effects for sugarcane yield components and implications for hybridization. Trop. Agric. (Trinidad) 68: 376-80.

[15] Tyagi, A. P. and P. Lal (2007). Correlation and path coefficient analysis in sugarcane. South Pacific J. Nat. Sci. 25: $1-9$.

[16] Péné, C. B., H. M. Ouattara and G. S. Koulibaly (2012). Late season sugarcane performance as affected by soil water regime at the yield formation stage on commercial farms in northern Ivory Coast. J Life Sci. 6 (6): 644-651.

[17] Konan, E. A., C. B. Péné and E. Dick (2017a). Main factors determining the yield of sugarcane plantations on Ferralsols in Ferké 2 sugar complex, Northern Ivory Coast. J. Emerg. Trends Engin. Appl. Sci. JETEAS 8 (6): 244-256.

[18] Konan, E. A., C. B. Péné, E. Dick (2017b). Caractérisation agro-climatique du périmètre sucrier de Ferké 2 au Nord de la Côte d'Ivoire. J Appl. Biosci. 116: 11532-11545.

[19] Tadesse, F., T. Negi, A. Getaneh, Z. Dilnesaw, N. Ayele and Y. Teferi (2014). Genetic variability and heritability of ten exotic sugarcane genotypes at Wonji sugar estate of Ethiopia. Global Adv. Res. J. Phys. Appl. Sci. 3 (4): 1-4. 
[20] M. Hoarau. La canne à sucre. Le technician d'agriculture tropicale. Maisonneuve et Larose (eds), 1970, $165 \mathrm{p}$.

[21] E. Hugot. Sucrerie de canne. Paris, Collection Tech \& Doc, Lavoisier (eds), 1999, $1018 \mathrm{p}$.

[22] Burton, G. W., E. H. Devane (1953). Estimating heritability in tall Fescue (Festuca arundinacea) from replicated clonal materials. Agron. J.: 45: 487-88.

[23] Shitahum, A., T. Feyissa and D. Abera (2018). Performances evaluation of advanced sugarcane genotypes (Cirad 2013) at Metahara sugar estate, Ethiopia. Int. J Adv. Res. Biol. Sci.: 5 (1): 91-104.

[24] R. K. Singh and B. D. Chaundary. Biometrical methods in quantitative genetics analysis. New Delhi, Kalyani Publishers, 1977: 57-8.

[25] D. S. Falconer, T. F. C. Mackay. Introduction to quantitative genetics. $4^{\text {th }}$ eds. Harmlow: Longman, 1996.

[26] Jackson, P., J. Basnayake, G. Inman-Bamber, P. Lakshmanan, S. Natarajan and C. Stokes (2015). Genetic variation in transpiration efficiency and relationships between whole plant and leaf gas exchange measurements in Saccharum spp. And related germplasm. J. Experim. Bot: 67 (3): 861-71.

[27] Rebettzke, G. J., A. G. Condon, R. A. Richards and G. D. Farquhar (2002). Selection of carbon isotope discrimination increases aerial biomass and grain yield of rainfed bread wheat. Crop Sci.: 42 (3): 739-45.

[28] Kang, M. S., J. D. Miller and P. Y. P. Tai (1983). Genotypic and phenotypic path analyses and heritability in sugarcane. Crop Sci: 23: 643-47.

[29] Dagar, P., S. K. Pahuja, S. P. Kaian and Singh (2002). Evaluation of phenotypic variability in sugarcane using principal factor analysis. Ind. J. Sugarc. Technol: 17: 95100 .

[30] Ebid, M. H. M., H. A. Khalil, A. M. Abd-ElAal and M. A. Fergany (2015). Heritability and genotypic and phenotypic correlations among sugarcane yield and some agronomic traits. Egypt L Plant Breed: 19 (1): 159-71.

[31] A. R. Hallauer and J. B. Miranda. Quantitative genetics in maize breeding. Iowa State Univ. press, Ames, Iowa, 1988, p. 468 .

[32] D. S. Falconer. Introduction to quantitative genetics. $3^{\text {rd }}$ eds. Longman, UK, 1989, p. 430.

[33] Ram, B., G. Hemaprabha (1992). Genetic variability in interspecific progenies in sugarcane (Saccharuim spp.). Ind. J. Genet: 52 (2): 192-98.

[34] Chaudhary, R. R. (2001). Genetic variability and heritability in sugarcane. Nepal Agric. Res. J: 4: 56-9.

[35] Kimbeng, C. A., A. R. Rattey and M. Hetherington (2002). Interpretation and implications of $\mathrm{GxE}$ interactions in advanced stage sugarcane selection trials in central Queensland. Aust. J. Agric. Res. 53 (9): 1035-45.

[36] R. C. Parfitt. Genotype x environment interaction among secondary variety trials in the northern region of the South African sugar industry. Proc. S. Afr. Sug. Technol. Assoc, 2000: 74: 245-58.

[37] Glaz, B. and M. S. Kang (2008). Location contributions determined via GGE biplot analysis of multi-environment sugarcane genotype-performance trials. Crop Sci. 48: 94150 .

[38] K. A. Gomez and A. A. Gomez. Statistical procedure for agricultural research $\left(2^{\text {nd }}\right.$ ed). John Wiley and Sons Inc, New York. 1984.

[39] Gravois, K. A. and S. B. Milligan (1992). Genetic relationship between fibger and sugarcane yield components. Crop Sci. 32 (1): $62-7$.

[40] Dumont, T., A. Thong-Chane, L. Barau, B. Siegmund and J. Y. Hoarau (2019). Genetic variability and genetic gains for yield components in regional sugarcane breeding program on Reunion Island. Sugar Tech. Available online http://doi.org/10.1007/s12355-019-00718-9.

[41] Péné, C. B., B. M. Boua, Y. Coulibaly-Ouattara and F. R. Goebel (2018). Stem borer (Eldana saccharina W) infestation outbreak in Sugarcane plantations of northern Ivory Coast: Management strategies under implementation. Amer. J Biosci. Bioeng. 6 (4): 27-35.

[42] Shivasubramanian, S. and M. Menon (1973). Heterosis and inbreeding depression in rice. Madras Agric. J. 60: 1139.

[43] Mancini, M. C., D. C. Leite, D. Perecin (2012). Characterization of the genetic variability of a sugarcane commercial cross through yield components and quality parameters. Sugar Tech. 14 (2): 119-25.

[44] Li, C. (2017). Genotypic variations in transpiration efficiency due to differences in photosynthetic capacity among sugarcane-related clones. J. Exper. Bot. 68 (6): 2377-85.

[45] Singh, R. K., D. N. Singh, S. K. Singh and H. N. Singh (1994). Genetic variability and correlation studies in foreign commercial hybrids of sugarcane. Agric. Sci. Dig. 14: 103-7.

[46] Dos Santos Silva, PP, M. Soussa and E. J. De Oliveira (2019). Prediction models and selection of agronomic and physiological traits for tolerance to water deficit in cassava. Euphytica 215 (4): 73.

[47] Ram, B. (2005). Estimation of genetic parameters in different environments and their implications in sugarcane breeding. In. J. Genet. 52 (2): 192-98.

[48] Fartek, B., S. Nibouche, T. Atiama-Nurbel, B. Reynaud and L. Costet (2014). Genotypic variability of sugarcane resistance to aphid Melanaphis sacchari, vector of the Sugarcane Yellow Leaf Virus. Plant Breed. 133 (6): 771-6.

[49] Robinson, H. F. (1966). Quantitative genetics in relation to breeding of the centennial of mendalism. Indian J. Gen. 26: 171-87.

[50] Teklu, D. H., S. A. Kebede and D. E. Gebremichael (2014). Assessment of genetic variability, genetic advance, correlation and path analysis for morphological traits in sesame genotypes. As. J. Agric. Res. 8 (4): 181-194.

[51] Nair, N. V., K. G. Somarajan and Baasundaram (1980). Genetic variability, heritability and genetic advance in Saccharum officinarum. Int. Sugar J. 82 (981): 275-6.

[52] Singh, G. P., K. R. Maurya, B. Prasad and A. K. Singh (1994). Genetic variability in Capsicum annum L. J. Appl. Biol. 4: 1922. 
[53] Vidya, KL, S. K. Oommen and K. Vijayaraghava (2002). Genetic variability and heritability of yield and related characters in yard-long bean. J. Trop. Agric. 40: 11-3.

[54] Butterfield, M. K. and K. J. Nuss (2002). Prospects for new varieties in the medium to long term: The effects of current and future breeding strategy on variety characteristics. In: Proceed. S. Afric. Sugar Ind. Agron. Assoc., Kwa-Shukela: 41-8.

[55] Shoba, D., N. Manivannan, P. Vindhiyavarman (2009). studies on variability, heritability and genetic advance in groundnut (Arachis hypogea L). Electron. J. Plant Breed. 1 (1): 74-7.

[56] Bakshi, R. (2005). Estimation of genetic parameters in different environments and their implications in sugarcane breeding. Indian J. Gen. 65 (3): 219-20.

[57] Pandey, R. A. (1989). Variability study in the hybrid progenies of sugarcane (Saccharum complex). Bharatiya Sugar: 49-51.

[58] Patel, MM, H. S. Patel, A. D. Patel and M. P. Patel (2008). Correlation and path analysis in sugarcane. Ind. Sugar 31: 911-14.

[59] Tefera, A, A. Sentayehu, T. Leta (2017). Genetic variability, heritability and genetic advance for yield and its related traits in rainfed lowland rice (Oriza sativa L) genotypes at Fogera and Pawe, Ethiopia. Adv. Crop Sci. Technol. 5 (2): 1000272. 